Gražina Miniotaitè

Generolo Jono Žemaičio Lietuvos karo akademija

Kultūros, filosofijos ir meno institutas

\title{
Kariuomenès modelio konstravimas Lietuvos politiniame diskurse
}

\begin{abstract}
Straipsnyje nagrinejjama Lietuvos kariuomenės ir kario ịvaizdžio konstravimo ypatybės Lietuvos politiniame diskurse. Jame mėginama atsakyti į klausimą, ar oficialiame diskurse konstruojama Lietuvos kariuomenès kaip NATO ginkluotuju pajègu sudètinės dalies samprata bei perẻjimas prie profesionalios kariuomenès nedisonuoja su Lietuvos vidaus politikai būdinga orientacija į tautinę valstybę? Straipsnyje kariuomenès ir kario įvaizdžio pokyčiai analizuojami platesniame istoriniame/kultūriniame kontekste, siejant juos su modernybės/pomodernybės normatyvinių nuostatų sąveika Lietuvos politiniame diskurse bei valstybės tarptautinio identiteto konstravimo ypatybèmis. Visuomeninės nuomonės kariuomenės transformacijos klausimais apžvalga patvirtina bendrą pagrindinių strateginių dokumentų analizès išvadą - dabartinè Lietuva yra pereinamajame laikotarpyje nuo modernios tautinès valstybės vertybinių nuostatu prie pomodernios visuomenès vertybinio modelio. Reformuojant Lietuvos kariuomenę, būtų tikslinga atsižvelgti į šią jos specifiką.
\end{abstract}

\section{Ivadas}

Pastaraisiais metais politikos moksluose pastebimai padaugëjo studijų kuriose analizuojamos kariuomenės ir kario įvaizdžio transformacijos demokratinėse valstybėse po Šaltojo karo ${ }^{1}$. Kaip pažymëjo Moskos „ideali nacionalinės kariuomenės forma, siejama su visuotine karine prievole, vyriškomis vertybėmis ir nacionaliniu patriotizmu transformuojasi ị aukšto techninio lygio profesionalias ginkluotąsias pajėgas, suteikiančias galią laikinoms tarptautinėms koalicijoms ${ }^{\text {“2}}$. Šie kariuomenès pokyčiai dažnai konceptualizuojami kaip

\footnotetext{
${ }^{*}$ Dr. Gražina Miniotaité - Lietuvos karo akademijos Politikos mokslų katedros profesorè, Kultūros, filosofijos ir meno instituto vyresnioji mokslo darbuotoja. Adresas: Šilo g. 5 A, 10322 Vilnius, tel. 8-5 2103569, el. paštas-grazina.m@gmail.com,

1 Žr.: Latham, A., „Warfare Transformed: A Braudelian Perspective on the „Revolution on Military Affairs““, European Journal of International Relations, 2002, vol. 8(2), p. 231-66; Moskos Ch. C., Williams J., Segal D., eds., The Postmodern Military: Armed Forces after the Cold War, New York: Oxford: Oxford University press, 2000; Heurlin B., Kristensen K., Rasmussen M. \& S. Rynning, eds., New Roles of Military forces, Copenhagen: Danish Institute for International Studies, 2003; Clearly L. R., McConville T., eds., Managing Defence in a Democracy, London: Routledge, 2006; Jabri V., War and the Transformation of Global Politics, Houndmills and New York: Palgrave Macmillan, 2007.

2 Moskos, Ch., Burk, J., „The Postmodern Military“ in Burk J., ed., The Military in New Times. Adapting Armed Forces to a Turbulent World, Boulder: West View Press, 1994, p. 145.
} 
perëjimas nuo modernios prie pomodernios kariuomenės. Tokio konceptualizavimo šaltinis yra socialiniuose ir humanitariniuose moksluose įsitvirtinęs visuomeniu skirstymas i modernias ir pomodernias ${ }^{3}$.

Pagrindiniai kriterijai, apibrèžiant kariuomenę kaip modernią ar pomodernią yra ne tik techninis kariniu pajėgumu lygis, o jų funkciju, santykio su visuomene, kario îvaizdžio ypatybès ${ }^{4}$. Sios ypatybės siejamos su skirtingomis tautos ir valstybės santykio, suvereniteto pagrindu bei tarptautinės sistemos sampratomis modernybès ir pomodernybès epochose. Modernybëje, kurios turinys siejamas su pramonine revoliucija Europoje bei su vertybinemis apšvietos epochos nuostatomis ${ }^{5}$ formuojasi vadinamas Vestfalijos valstybiu sistemos modelis. Jame pagrindinis tarptautinès politikos veikèjas konceptualizuojamas kaip tautinè valstybè, sienos kaip aiškiai apibrèžtos teritorinès linijos, o tvarka kaip stabilus galios pasiskirstymas tarp suverenių valstybių Vestfalijos santykių tarp valstybių sistema išsilaikė iki pat Šaltojo karo pabaigos; pagrindinès ją kuriančios distinkcijos yra vidus/išore (ang inside/outside), anarchija/hierarchija, aš/kitas (ang. self/other). Pasaulis joje yra padalijamas i saugu, racionaliai valdomą tautinès valstybès vidų ir pavojingą, anarchinę, neprognozuojamą išorę, į taikos ir grésmès zonas.

Vestfalijos modelyje suverenitetas yra pagrindinis modernią politinę sistemą organizuojantis principas. Jame valstybè suvokiama kaip kiekvienos tautos tikslas, o ne kaip jos kultūrinio ir socialinio vystymosi priemonè ${ }^{7}$. Modernioje valstybeje jos suvereniteto legitimumo šaltinis yra tauta. Šią mintị teorinių modernios valstybės pagrindų kūrèjai T. Hobsas ir D. Lokas išreiškè hipotetinio tautos ir valdžios kontrakto metafora. Tam, kad būtų užtikrintas tautos ir valstybès saugumas, tauta per hipotetinį socialinį kontraktą suteikia valdžiai prievartos monopoliją. Tokia suvereniteto pagrindu samprata iš esmès keičia kariuomenès kūrimo bei santykio tarp valstybės ir piliečiu pagrindimą. Būdama valstybės suvereniteto šaltiniu, tauta tuo pačiu igyja visuotinę pareigą ją ginti. Şi ypatingą santykị tarp tautos ir valstybės išreiškia nauja kario samprata, visuotinės karo prievolès institucijos atsiradimas. Šalia pareigos ginti valstybę, kariui suteikiama moralinè teisẻ žudyti valstybės, tautos vardu. Modernioje valstybëje šalies gynyba, jos pagrindimas ir su tuo susijusios institucijos tampa svarbiu tautiškumą konstruojančiu ir palaikančiu faktoriumi, nacionalinio solidarumo (identiteto) dalimi.

\footnotetext{
Kai kurie autoriai istoriškai visuomenes skirsto į ikimodernias, ankstyvają modernybę, modernias ir pomodernias. Žr.: Baudrillard J., Simulacra and Simulation, Ann Arbor: The University of Michigan Press, 1994; Moskos Ch. C., ,Towards A Postmodern Military: The United States as a Paradigm“ in Moskos Ch. C., Williams J., Segal D., eds., The Postmodern Military: Armed Forces after the Cold War, New York: Oxford: Oxford University press, 2000.

4 Moscos, (3 nuoroda), p. 15.

5 Žr.: Habermas, J., Modernybès filosofinis diskursas, Vilnius: Alma littera, 2002.

${ }^{6}$ Mathias A., Jacobson D.,and Lapid Y., eds., Identities, Borders, orders: Rethinking International Relations Theory, Minnesota: University of Minnesota Press, 2001, p. 7.

7 Browning, Chr. „From Modern to Post-Modern Region_Building: Emancipating the Finnish Nation from the State" in Lehti M., \& Smith D., eds., Post-Cold War Identity Politics: Northern and Baltic Experiences, London: Frank Cass, 2003, p.108.
} 
Pomodernybės epocha yra susijusi su šiuolaikiniais integracijos ir globalizacijos procesais bei su tautinès valstybès, kaip pagrindinès politinès erdvės organizavimo formos, reikšmės mažèjimu. Tautinis identitetas praranda ontologinị natūralumą, tapdamas vienu iš socialiniu konstruktų. Atsiranda persidengiančių identitetų samprata, griaunanti Herderio ir Hegelio teiginį, kad individo esmė yra tautoje, o tautos esmè valstybëje. Šiuos pokyčius lydi tolerancijos kitybei (ang. otherness), decentralizacijos ir fragmentacijos pateisinimas, postuluojant universalias visuotines žmogaus teises. Tautinio identiteto atsiejimas nuo teritorinio suvereniteto keičia nacionalinio saugumo, suvereniteto, valstybès vaidmens sampratas. Tai savo ruožtu keičia kariuomenės vietą visuomenëje, formuoja naują kario įvaizdį.

Kaip pastebi daugelis autoriu, šiuolaikinëje pomodernioje visuomeneje, kurioje pagrindinis vertybinis krūvis tenka žmogaus teisėms, aiškinantis visuomenès solidarumo pagrindų problemą, kyla nemažai klausimų. Ar pagarba žmogaus teisèms gali tapti solidarumo su tolimu "svetimuoju“ pagrindu? Ar imanomas globalus socialinis kontraktas, grindžiamas fundamentaliomis žmogaus teisėmis? Ar šiuolaikinis karys pasiryžęs mirti dèl žmonijos ${ }^{8}$ ? Absoliutizuojant tolerancija kitybei, nepastebimai išnyksta riba tarp gèrio ir blogio. Šiuolaikinis karys kovoja ne prieš konkretų blogi, o dèl abstraktaus gèrio (force for good). Tolerancijos suabsoliutinimas ir su tuo susijęs politinis korektiškumas neleidžia aiškiai apibrèžti priešą; jo sampratai stinga kultūrinio savitumo, po rugsëjo 11-osios tai kosmopolitinis teroristas. Susidaro paradoksali situacija, postmodernus karys, ikuunydamas „gèrio jëgą" taiko ją ikimoderniose ar moderniose visuomenėse, kurioms būdinga visiškai kita gynybos ir grèsmès samprata, o tai tik didina susvetimëjimą tarp dèl gèrio kovojančio kario ir ginamujų. Globalias žmonijos ir demokratijos plètros sąlygas ginantis karys susiduria su iš lokaliu problemų neišbrendančiais Somalio ar Afganistano gyventojais, kuriems jūrų piratavimas ar aguonų auginimas yra ne kriminalinè veikla, o išgyvenimo būdas?.

Lietuvoje ir politikos analitikai ir plačioji visuomenè taip pat skiria daug dėmesio esminių šalies kariuomenės pokyčių analizei. 1992 metais atsikūrusi Lietuvos kariuomenè per labai trumpą laiką turèjo persiorientuoti nuo tautinès valstybès savarankiškos teritorinès gynybos normatyvinio modelio prie kolektyvinès gynybos reikalavimu. Šiuos procesus ir su jais susijusias problemas tyrẻ Kęstutis Paulauskas, Vaidotas Urbelis, Algirdas Gricius, To-

${ }^{8}$ Kaldor M., Global Civil Society. An Answer to War, Cambridge: Polity, 2003, p. 136.

9 Žr.: Enterline A. J.and J. M. Greig, ,The history of imposed democracy and the future of Iraq and Afghanistan“, Foreign Policy Analysis, 2008, vol. 4/4, p. 321-347. Straipsnyje, išnagrinëjus 43 ,ivestos“ (ang. imposed) demokratijos atvejus 1800-1994 metais, daroma išvada, kad jos išgyvenimas ,jokiu būdu nèra garantuotas" (,the survival of imposed democracy is by no means assured“, p. 322). 
mas Jermalavičius ir kiti ${ }^{10}$. Jūratė Novagrockienė savo darbuose parodè, kad kariuomenès skirstymas į modernią/pomodernią gali būti sẻkmingai taikomas, analizuojant Lietuvos kariuomenès transformacijas ${ }^{11}$. Šiame straipsnyje, tęsiant kitų autorių tyrimus, mėginama atsakyti į klausimą, ar oficialiame diskurse konstruojama Lietuvos kariuomenès kaip NATO sudètinès dalies samprata bei perejjimas prie profesionalios kariuomenès nedisonuoja su Lietuvos vidaus politikai būdinga orientacija į tautinę valstybę? Straipsnyje kaip ir minėtuose darbuose kariuomenės ir kario įvaizdžio pokyčiai analizuojami platesniame istoriniame/ kultūriniame kontekste, siejant juos su modernybès / pomodernybès normatyvinių nuostatų sąveika Lietuvos politiniame diskurse bei jos tarptautinio identiteto konstravimo ypatybemis. Kaip buvo parodyta ankstesniuose darbuose $^{12}$, Lietuva, tapusi ES ir NATO nare, igyja vis daugiau pomodernios valstybės bruožuc, tačiau jos politinio identiteto konstravimas orientuojasi į modernios valstybès modelį.

Straipsnyje, analizuojant kariuomenès ir kario įvaizdžio Lietuvoje transformacijas, remiamasi konstruktyvistine šiuolaikinio politinio diskurso analize, papildoma ekskursais į Lietuvos kariuomenès istoriją. Diskursas yra suprantamas plačiaja prasme, tai - diskursyvinių praktikų visuma, kurianti ir organizuojanti socialinius santykius pagal tam tikrą reikšmių struktūrą ${ }^{13}$. Diskurso analizès teorija teigia, kad diskursyvinès praktikos yra ideologinès, nes jos prisideda prie atsitiktinai sukonstruotų reikšmių natūralizmo. Ideologinis diskursas prisideda ne tik prie socialinės ir politinès tvarkos palaikymo, bet ir prie jos transformacijos. Diskurso analizės tikslas - atskleisti ryšį tarp teiginių reikšmių ir jų institucinių formu, tarp politinių sprendimų ir jų ígyvendinimo galimybių. Tokia analizė gali išryškinti neatitikimą tarp idëjų ir jas įkūnijančių materialių struktūru, o tai leidžia spręsti apie struktūrų efektyvumą/neefektyvumą suformuluotų tikslų atžvilgiu.

Šiame teoriniame kontekste atrodo tikslinga Lietuvos ginkluotuju pajėgų transformaciją nagrinèti kaip modernybės ir pomodernybès diskursų sąveikos rezultatą. Straipsnyje, analizuojant oficialius saugumo politiką bei kariuomenès funkcionavimą apibrěžiančius dokumentus, siekiama atskleisti kurios - modernybės ar pomodernybės reikšmės juose vyrauja. Teksto priklau-

\footnotetext{
${ }^{10}$ Žr: Paulauskas K. „The Driving Logic Behind the Defence Reform in Lithuania: Building the Future Military“, Baltic Defence Review, 2003, vol 9/1, p.126-134. Urbelis V., „ Impact of NATO Membership on Military Service in the Baltic States / Service to Country" in Gilroy C., Cindy W., eds., Personnel Policy and the Transformation of Western Militaries, Cambridge: MIT Press, 2006; Urbelis V. „Democratisation and integration: DCAF in the Baltic states" in Vankovska B., ed., Legal aspects of Civil-Military relations in Central and Eastern Europe, Geneva: Geneva Centre for Democratic Control of the Armed Forces, 2002, p. 109-124; Jermalavičius T., „Karo prievolè Lietuvoje: orientyrai diskusijai“ žr.: Novagrockienė J., sud., Profesionalioji kariuomené: Vakaru šaliu patirtis ir perspektyvos Lietuvoje, Vilnius: Lietuvos karo akademija, 2005, p. 8-29; Gricius A., Paulauskas K., „Demokratinè civilinè ginkluotujų pajėgų kontrolè Lietuvoje“, Lietuvos metinè strateginè apžvalga 2002, p. 217-236.

${ }^{11}$ Novagrockienė J., ,Kariuomenès transformacija XXI amžiuje: Lietuvos atvejis“, Lietuvos metiné strategine apžvalga 2004, p. 197-214.

${ }^{12}$ Žr.: Miniotaite G., „The Baltic States: In Search of Security and Identity” in Krupnick Ch.,ed., Almost NATO: Partners and Players in Central and Eastern European Security, Lanham, Md: Rowman \& Littlefield, 2003, p. 261-296.

${ }^{13}$ Žr.: Foucault M., The Archaelogy of Knowledge, New York: Pantheon Books, 1972.
} 
simą modernybės ar pomodernybės diskursui parodo tautos, valstybės, saugumo / gynybos, grèsmès, ginkluotuju pajegu struktūros, jų misijos, kario sampratos ${ }^{14}$. Išskirti kriterijai neapima visų C. Moscos pateikiamų kriterijų. Kaip pažymi pats autorius, jo siūlomas modelis apima demokratinių išsivysčiusių Vakarų valstybių kariuomenių tyrimus. Tuo tarpu straipsnyje modernybès/pomodernybès normatyviniu prielaidų kontekste yra nagrinejama vos nuo 1992 metų egzistuojančiu ginkluotoju pajègu evoliucija. Išsiaiškinus, kokia ginkluotuju pajègu samprata yra konstruojama oficialiuose dokumentuose, ji yra gretinama su diskusijose ir viešosios nuomonès tyrimuose atsiskleidžiančiu kariuomenès ir kario įvaizdžiu. Atitinkamai straipsni sudaro trys dalys, analizė pradedama trumpu ekskursu i Lietuvos tarpukario kariuomenès istoriją. Šioje dalyje pagrindinis dėmesys skiriamas toms jos savybėms, kurios turëjo ir turi įtakos šiuolaikinio ginkluotujų pajėgu modelio konstravimui. Toliau pereinama prie oficialių dokumentu, apibrèžiančių Lietuvos saugumo ir gynybos politiką, bei kitų susijusių oficialių tekstu, analizės, atskleidžiant juose pateikiamą kariuomenės ir kario įvaizdžio sampratą. Trečioji darbo dalis analizuoja visuomenės požiūrị į Lietuvos ginkluotąsias pajėgas.

\section{Lietuvos kariuomenès vaidmuo ir vieta tarpukario Lietuvoje.1918-1940}

Daugeliui šiuolaikinių išsivysčiusių valstybių būdingas perëjimo nuo modernios prie pomodernios kariuomenès procesas kiekvienoje šalyje igauna konkrečią formą, nuspalvintą jos istorijos interpretaciju, mitais virtusiu ịvykių apie Tèvynės gynëjų herojiškumą. Lietuviams tai kryžiuočių ordino kronikose aprašytas Pilènų pilies gynimas. 1336 metais pilies gynejjai, po ilgos permainingos kovos, nenorèdami pasiduoti kryžiuočiams, sudegino pili su visu turtu ir susidegino patys kartu su visais pilyje buvusiais žmonėmis. Po to Lietuvos didžiosios kunigaikštystès kariai laimëjo daugybę įspūdingų mūšiu, tačiau, būtent šis pralaimètas mūšis, atspindètas įvairiuose meno kūriniuose, tapo lietuvių identiteto dalimi. Jame aiškiai iškyla dvasiškai nepalaužiamo, neatsiejamo nuo savo šaknu, kario - Tẻvynès gynejo figūra. Nepaisant šio i̇vaizdžio archajiškumo, jis tapo ịkvėpimo šaltiniu Lietuvos nepriklausomybės gynejjams 1991 metais sausio mėnesi, kai sprendèsi Lietuvos valstybingumo išlikimo klausimas ${ }^{15}$.

\footnotetext{
${ }^{14}$ Žr.: Novagrockienė (11 nuoroda), p. 202.

${ }^{15}$ I991 metų sausio 11-13 dienomis Sovietų Sajunga mėgino įvykdyti perversmą, kurio tikslas buvo užgniaužti 1990 metų kovo 11 atkurtą Lietuvos valstybės nepriklausomybę. Buvo neabejojama, kad Sovietų desantininkai mėgins užimti parlamentą, paskelbusi nepriklausomybę. Jei toks puolimas būtų ịvykęs, parlamento pastatas, dèl jame buvusių „Molotovo kokteilių“ ir kitų gynybai paruoštų priemonių, būtų virtęs dar vienu Pilènu laužu. Nepaisant šios grèsmės, parlamentarai buvo savo vietose, pastate buvo daugybė savanorių. Be to, pastatą gyva siena apsupo gyventojai, atvažiavę iš visos Lietuvos ginti nepriklausomybès. Galbūt, dẻl šių aplinkybių, dẻl žmonių pasiryžimo antriems Pilènams, sovietų desantininkams nebuvo duotas isakymas šturmuoti pastatą.
} 
Pilėnu mito gyvybingumas Lietuvos politiniame diskurse parodo, kad šalies gynybą gyventojai yra linkę suvokti kaip totalinę gynybą, kurioje gyneju tampa kiekvienas jos gyventojas. Kariuomenè yra būtinas šalies saugumo instrumentas, kurio veiksmingumą, esant kritinėms situacijoms, gali sustiprinti visu gyventoju parama. Kita vertus, šalia šio, gimtujų namų gynèjo įvaizdžio egzistuoja ir kitas - kareivio profesionalo įvaizdis. Tai susiję su Lietuvos valstybės istoriniais ypatumais. Susiformavusi 13 amžiuje, Lietuvos pagoniška valstybė, beveik keletą šimtmečiu buvo tarp galingiausiu krikščionišku Europos valstybių. Savo klestëjimo laikotarpiu LDK vykdẻ dvejopą gynybos ir užkariavimo politiką: vakaruose ji ryžtingai gynèsi prieš teutonų kryžiuočių ordiną, rytuose plètėsi į Rusijos žemes, įtvirtindama savo ekspansiją pergalèmis prieš totorius ir apgalvotomis vedybomis su kilmingomis Rusijos šeimomis ${ }^{16}$.

Šiuolaikinëje Lietuvoje tuometinis politikos dvilypumas atsispindi, viena vertus, kaip pasididžiavimas etniniu žemiu gynëjų herojiškumu ir, kita vertus, kaip žavejimasis kariuomenès profesionalumu, jos pergalingais žygiais, prisijungiant naujas teritorijas (kalbant šiuolaikine kalba, plečiant savo saugumo erdvę G. M.). Galima teigti, kad Lietuvos didžiosios kunigaikštystės istorija itteisina ir kario gynejo ir svetimuose kraštuose kariaujančio kario profesionalo įvaizdžius. Tačiau šiuolaikinio kario įvaizdžio formavimuisi kur kas svarbesnis yra tarpukario Lietuvos (1918-1940) saugumo ir gynybos politikos patyrimas, jos kariuomenès kūrimo ir žlugimo istorija.

Beveik nuo pirmuju Lietuvos nepriklausomybės paskelbimo dienų 1918 metais, valstybės egzistencijai grèsė pavojus. İ etnines lietuvių žemes ginklu pretendavo Lenkija, ir Sovietu Rusija. Savalaikis kovingos kariuomenė sukūrimas buvo valstybės išlikimo sąlyga. 1918 metu pavasarị ji buvo suformuota iš savanorių. 1918-1920 metais Lietuvos kariuomenė sẻkmingai kovojo su bolševikine Rusija, bermontininkais, lenku ginkluotomis pajëgomis. Lietuvos kariuomenėbuvo kuriama ypatingomis aplinkybėmis, valstybės sienos buvo nustatytos ne Tautu lygos, o nubrèžtos ir lietuvių ir ju priešininku ginklu; kariai, gindami šalies nepriklausomybę, tuo pačiu apibrěžej jos teritoriją. İtempti santykiai su Lenkija beveik visą tarpukario laikotarpi vertė Lietuvą turèti didžiulę kariuomenę. 1922 metu pradžioje Lietuvos kariuomenëje tarnavo 52965 kariai irji buvo kovinëje parengtyje. Kariuomenę sudare 13 pėstininku, 3 kavalerijos, 4 artilerijos pulkai, karo aviacijos dalinys (12 lèktuvų), šarvuočiu rinktine, inžinerijos batalionas, pasienio apsaugos dalys ${ }^{17}$.

Kariuomenės struktūra, jos vieta ir vaidmuo visuomeneje priklausė nuo Lietuvos politinio režimo, kurio ypatybės atsispindi 1922 ir 1938 metu konstitucijose. Pirmoji, išreišké Lietuvos politinio elito orientaciją į liberalias vakaru Europos konstitucijas. Ji įtvirtino demokratinę valdymo formą, kuriai būdingas parlamento dominavimas, silpna vykdomoji valdžia ir

${ }^{16}$ Žr.: Smith D., Pabriks A., Purs A. and Thomas Lane, The Baltic States: Estonia, Latvia and Lithuania, London and New York: Routledge, 2002, p. XX.

${ }^{17}$ Surgailis G., Lietuvos kariuomené: 1918-1998, Vilnius: LR krašto apsaugos ministerija, 1998, p. 21. 
simbolinis prezidentas ${ }^{18}$. Demokratiniai 1922 metu konstitucijos principai atsispindejo ir visuomenès bei kariuomenès santykių nuostatose. Pagal 1919 m. balandžio mėn. Krašto apsaugos ministro įsakymą kariškiams buvo draudžiama dalyvauti politikoje, vyko laipsniškas ginkluotuju pajègu mažinimas.

Tačiau gana greitai paaiškejjo, kad Vakarų demokratijos modelis sunkai pritaikomas Lietuvos realijoms. Vykdomosios valdžios neveiksmingumas, partinès sistemos nebrandumas, pilietinès visuomenės silpnumas, tokiu įtakingų visuomenės grupių kaip kariškiai ${ }^{19}$ ir bažnyčia nepasitenkinimas sudarè prielaidas 1926 metų valstybiniam perversmui. Jo įtvirtintą režimą įteisino 1938 metų konstitucija. Priešingai pirmajai, joje įteisinamas vykdomosios valdžios prioritetas, sukoncentruotos prezidento Antano Smetonos rankose. Smetonos režimas gali būti apibrèžtas kaip autoritarinis nacionalizmas. Jam būdingas politinių ir pilietinių laisvių apribojimas ir tautos vado kultas, grindžiamas tokiomis sąvokomis kaip tautos valia, tautos solidarumas, ištikimybe bendram tikslui, tautos disciplina.

Smetonos režimo metais vyko laipsniška visuomenės militarizacija, šauktiniais grindžiamos kariuomenės ir karininkų vaidmens visuomenėje didëjimas. Tai akivaizdžiai matyti iš lèšu, skirtu ginkluotosioms pajėgoms augimo: per nepriklausomybės laikotarpi jos išaugo nuo 16 iki 25 (1938 m.) procentų valstybès biudžeto $^{20}$. Karininkijos kišimąsi į politiką netiesiogiai rodo aukštų karininkų dalyvavimas 1934 metų voldemarininkų puče. Prie draudimo karininkams dalyvauti politikoje grižztama tik ketvirtame dešimtmetyje Stasiui Raštikiui tapus kariuomenès vadu. Tuo metu ypatingai daug dėmesio buvo skiriama ginkluotuju pajègu įvaizdžio pagerinimui, mažinant atotrūkị tarp kariuomenès ir visuomenès. Siekiant padidinti kariuomenès autoritetą visuomenëje, buvo plačiai naudojama radijas, spauda, organizuojami įvairūs renginiai, atviru durų dienos. Ypatingai populiarios buvo kartą i metus rengiamos visuomenès ir kariuomenės suartèjimo šventès. Tačiau tarpukario Lietuvos spaudoje praktiškai „nebuvo nagrinëjamas karių profesinės atsakomybės klausimas, tiek visos kariuomenès visuomenei, tiek individualios atsakomybės “21.

Svarbiausiomis kario vertybėmis buvo laikoma meilè Tẻvynei, patriotizmas, drausmè. Kuriant karinio ugdymo institucijas, buvo keliami ne tik kario profesijos įvaldymo uždaviniai, bet ir siekiama „išleisti jaunus karininkus grynai lietuvių dvasios, kuri yra atspindys mūsų garbingų karžygių

\footnotetext{
${ }^{18}$ Smith (16 nuoroda), p. 19.

${ }^{19} 1922$ metais prasidèjęs kariuomenès mažinimas, ypatingai sustiprèjęs po 1926 metų rinkimų, kẻlè didžiuli karininkų nepasitenkinimą. Kariuomenès vadovybè palaikè 1926 metų gruodžio mėnesio valstybinị perversmą.

${ }^{20}$ Smith (16 nuoroda), p. 26.

${ }^{21}$ Petrauskaitė A. „Karininkijos dorovinių problemų sprendimas Lietuvoje 1918-1940 m.“ žr.: Ažubalis A., R. Kazlauskaitè-Markelienè, A. Petrauskaitė, B. Puzinavičius, F. Žigaras, Karo pedagogika Lietuvoje (1918-1940m.), Vilnius: Lietuvos karo akademija, 2007, p. 291.
} 
senoliu“ “22. Karininkai turëjo sudaryti naujosios Lietuvos elitą, tačiau, kaip pažymi A. Petrauskaitė, laikui bėgant „,karininko sąmonėje įsitvirtino požiūris, kad kariai yra už visuomenės ribų (t. y. aukščiau jos), kad karininko profesija yra ne profesija, o „gyvenimo būdas “23. Kaip tuo metu rašè plk. A. Žukas: „kariška garbe்" yra atskira garbès rūšis, nes tai "kastinė garbè, „luominè dora“, nes „mes karininkai - profesionalai sudarom atskirą luomą, net daugiau negu luomą - kastą, todèl ir turime be bendro supratimo apie garbę ir dorą, dar savo kastinį supratimą “24. Profesijos išskirtinumą palaikè ir gana detalus ir griežtas elgesio reglamentavimas, palaikomas drausmès statutais, garbės teismais. Šis reglamentavimas apėmė ir karininkų šeimos narius.

Kariuomenei smetoninëje Lietuvoje teko dvejopos funkcijos: pirma, valstybės nepriklausomybès, jos saugumo nuo pagrindinio išorès priešo - Lenkijos, garantas, ir antra, valstybės (tautos), suvokiamos kaip vieningas organizmas, konsolidavimo, jos gyventoju solidarumo užtikrinimo instrumentas. Pažymėtina, kad nuo 1920 metų kariuomenė nẻ karto nebuvo panaudota šalies gynybai. Ji nepasipriešino 1938 metų Lenkijos ultimatumui, 1939 metų Klaipėdos praradimui, 1940 metų Sovietų invazijai. Atrodo, kad pagrindinè jos funkcija buvo garantuoti vidinị šalies stabilumą autoritarinio režimo sąlygomis. Kariuomenè atliko instrumentinę režimo palaikymo funkciją.

Šiuolaikinëje Lietuvoje ypatingai skausmingai yra suvokiamas kariuomenės neveiklumas 1940 metais. To laikotarpio Baltijos valstybių užsienio politiką nevienareikšmiškai vertina ir istorikai ${ }^{25}$, ir visuomenès veikẻjai. Dauguma jų neabejodami, kad 1940-uju tarptautinè situacija nepaliko Lietuvai šansu išsaugoti nepriklausomybę, teigia, kad „gèdingai kapituliacijai alternatyva

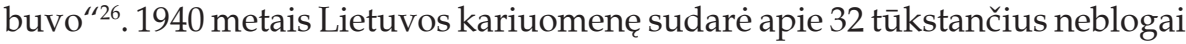
ginkluotų karių, (mobilizacijos atveju jų skaičių buvo galima padidinti iki 150 000 žmonių), 70 tūkst. šaulių ${ }^{27}$, gyventojai pasižymejjo tvirta tautine savimone. Tačiau kritinejje situacijoje ir tautos ir kariuomenès vadai pademonstravo nepasitikẻjimą tauta, nepalikdami jai vietos savo politiniuose skaičiavimuose. 1939 metų kovo mėn. kariuomenès vadas S. Raštikis kreipimesi į kariuomenę pareiškè: „Nepriklausomybe yra brangiausias tautos turtas, kuris turi būti ginamas visomis priemonemis, t. y. ir ginklu. Šioje kovoje geriau garbingai žūti ar net tą ginkluotą kovą su stipriausiu priešu garbingai pralaimèti, bet tik

\footnotetext{
22 Žigaras F., „Lietuvos kariuomenès karininkų rengimo ir jų kvalifikacijos tobulinimo sistema (1918-1940m.)“ žr.: Ažubalis (21 nuoroda), p. 27.

${ }^{23}$ Petrauskaitè (21 nuoroda), p. 287.

${ }^{24}$ Ten pat, p. 286.

${ }_{25}$ Žr.: Kirby D., „Incorporation: The Molotov-Ribbentrop Pact“ in Smith G., ed., The Baltic

States: The National Self-Determination of Estonia, Latvia and Lithuania, London: Macmillan, 1994, p. 80-81.

${ }^{26}$ Truska L., Lietuva 1938-1953 metais, Kaunas: Šviesa, 1995, p. 58.

${ }^{27}$ Ten pat.
} 


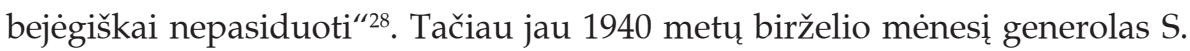
Raštikis, tuo metu jau ne kariuomenès vadas, buvo tarp tu, kurie pasisakė už Maskvos ultimatumo prièmimą.

Raudonosios armijos ịžengimas ị Lietuvą 1940 metų birželio mėnesį reiškė Lietuvos kariuomenės pabaigą. Likviduojant ir naikinant Lietuvos kariuomenę, apie 2 tūkst. karininkų ir apie 4,5 tūkstančius kareivių buvo suimta ir pateko į sovietų konclagerius, kuriuose dauguma buvo nužudyti arba mirẻ nuo nepakeliamu salygu $u^{29}$. Dalis kariuomenès buvo inkorporuota ị sovietu ginkluotąsias pajejgas. Vertinant tragiškus to meto įvykius, dažnai kaip alternatyva Lietuvos kapituliacinei politikai, pateikiamas ryžtingo suomių tautos pasipriešinimo sovietams pavyzdys, pamirštant paminèti, kad, skirtingai nuo autoritarinès Lietuvos, Suomija buvo demokratinė prezidentinè respublika. Lietuva beveik visą tarpukario laikotarpi gyveno karinès padèties sąlygomis, o tai labai sunkino pilietinès visuomenès formavimąsi. Kritinëje situacijoje Lietuvoje neatsirado alternatyvių politinių jëgų. Tai, kad visą nepriklausomybès laikotarpi puoselëjama Lietuvos kariuomenė lemiamu valstybei laikotarpiu pakluso valdžios nurodymams nesipriešinti svetimos kariuomenès invazijai, šiuolaikinëje Lietuvoje dažnai suvokiama kaip istorinè klaida, kaip tautos trauma. Mèginimai jos nepakartoti atsispindi daugelyje strateginių atsikūrusios Lietuvos valstybės dokumentu. Tam tikra kariuomenès reabilitacija, sugrą̌inusia tautai dali prarasto orumo, yra likusių gyvų karininkų ir karių dalyvavimas Lietuvos partizaniniame kare prieš Sovietų Sajungą 1944-1954 metais ${ }^{30}$.

Po šios trumpo istorinio ekskurso susidaro gana prieštaringas ịspūdis apie tarpukario Lietuvos kariuomenę. Viena vertus, tai buvo tipiška modernios tautinès valstybès kariuomenè, orientuota į tautos ir valstybès gynimą nuo gana aiškaus priešo. Be to,ji buvo tautiškumo ir gyventoju patriotinio ugdymo mokykla, svarbi nacionalinio identiteto dalis. Kita vertus, dèl to, kad kritinèse situacijose kariuomenè tapo politikų neatsakingumo įkaite, dalis atsakomybės tenka ir kariuomenės viršūnèms, pernelyg priartejjusioms prie tautos vado ir nutolusioms nuo tu, kuriuos ginti ji buvo ruošiama nuo pirmuju jos susikūrimo dienų. Kaip pažymëjo buvęs Viskonsino universiteto profesorius Vytautas Vardys, cituodamas S. Raštiki, tarpukario Lietuvos kariuomenè buvo „per daug didelëje politiku priklausomybëje ${ }^{\text {«31 }}$. Tačiau tai nebuvo demokratinėms visuomenėms būdingas kariškių pavaldumas civiliams, ,,bet greičiau kariškių naudojimas partiniams tikslams, t. y. politikavimas, besigrumiant dèl vietu, ir todèl daugiau demoralizuojantis nei demokratinis ${ }^{\iota / 32}$. Šie prieštaringi tarpukario Lietuvos kariuomenės vertinimai atsispindi ir kuriant šiuolaikinès Lietuvos kariuomenės modelị.

\footnotetext{
${ }^{28}$ LVVOA. - F. 1771. - Ap. 1. - B. 23- L. 2-3 (Cituojama pagal Truska (26 nuoroda), p. 55.).

${ }^{29}$ Surgailis (17 nuoroda), p. 72.

${ }^{30}$ Žr.: Gaškaitė N., Kuodytė D., Kašèta A., Ulevičius B., Lietuvos partizanai 1944-1953 m., Kaunas: Šviesa, 1996.

${ }^{31}$ Žr.: Vardys V., ,Generolo Raštikio memuarai ir jo vaidmuo Lietuvos politikoje“, Aidai, 1973, nr. 4. .http:// aidai.us/index.php?option=com_content\&task=view\&id=870\&Itemid=126, 20081103.

${ }^{32}$ Ten pat.
} 


\section{2. Šiuolaikinès Lietuvos kariuomenès modelio pagrindimas strateginiuose dokumentuose}

1990 metų kovo 11 d. Lietuvai deklaravus nepriklausomybę, SSR santykiuose su Lietuva vyravo ultimatyvus tonas: grasinimai sugriauti ekonomiką, atimti kai kurias teritorijas, supriešinti visuomenę. Lietuvos valdžia siūlè pradèti derybas ir, nepaisydama grasinimu, kūrè institucijas, įtvirtinančias valstybės suverenitetą. Jau 1990 m. kovo 12 d., kitą dieną po Lietuvos Respublikos atkūrimo akto paskelbimo, Lietuvos Respublikos Aukščiausioji Taryba prièmė nutarimą, kad SSRS karinès prievolès įstatymas Lietuvos piliečiams negalioja. Buvo priimtas Respublikos piliečio pažymèjimo įstatymas, pradètas valstybės sienų žymëjimas ir kontrolè, įsteigtas Lietuvos krašto apsaugos departamentas (1990 m. balandžio 25 d.). Kaip ir 1918 metais Lietuvos kariuomenè formavosi ne tik kaip valstybingumo simbolis, demokratijos garantas, o kaip nepriklausomybės gynëja ir sergètoja. 1992 m. lapkričio 19 d. Aukščiausioji Taryba - Atkuriamasis Seimas iškilmingai paskelbė, kad atkuriama Lietuvos Respublikos kariuomenè.

Kariuomenès kūrimas, jos struktūra ir funkcijos priklauso nuo bendros valstybès vizijos, nuo saugumo, grèsmių, sampratos. Lietuvos valstybės kūrimas vyko ypatingai sudètingomis sąlygomis, iki 1993 metų rudens jos teritorijoje buvo sovietų kariuomenè, teko spręsti gyvybiškai svarbius visuomenès ir valstybès transformacijos uždavinius. Neatsitiktinai nes nuo pat pirmuju valstybès kūrimo dienų didžiulis dèmesys buvo skiriamas jos saugumui. Kintanti tarptautinè aplinka bei Lietuvos valstybès statuso pokyčiai kelyje i ES ir NATO nuolat reikalavo iš naujo įvertinti saugumo situaciją bei valstybės uždavinius. Valstybès kūrimo procesas buvo ir tebèra lydimas daugybės įvairaus lygio strateginių dokumentų, kurių analizè leidžia atskleisti saugumo ir gynybos konceptualizavimo ypatybes. Šiuo aspektu straipsnyje bus nagrinejama Lietuvos konstitucija (1992), LR nacionalinio saugumo pagrindu įstatymas (1996), LR krašto apsaugos sistemos organizavimo ir karo tarnybos įstatymas (1998), LR Nacionalinio saugumo strategija (2002, 2005), LR Karinė strategija (2004).

\subsection{Lietuvos Respublikos Konstitucija, 1992}

1992 m. spalio 25 d. referendume priimta nauja Lietuvos Respublikos Konstitucija apibréžè Lietuvos valstybès politinès, teisinės ir ekonominès sistemos pagrindus, nustatė nacionalinio saugumo užtikrinimo ir valstybės gynimo principus. Konstitucija, pažymėdama, kad jos teisiniai pagrindai yra susiję su „Lietuvos Statutais ir Lietuvos Respublikos Konstitucijomis" (preambulè) išreiškia idejjinį dabartinès Lietuvos ryšį su jos istorinėmis šaknimis. Pagrindinėmis nuostatomis konstitucija yra artima Lietuvos 1922 metu konstitucijai, įkūnijusiai Vestfalijos valstybių modeliui būdingą suvereniteto sampratą. Sau- 
gumas joje suprantamas kaip nacionalinis saugumas, o gynyba kaip „Lietuvos valstybès gynimas nuo užsienio ginkluoto užpuolimo“(139 str.) ${ }^{33}$. Konstitucijai būdingas gana statiškas, Lietuvos istorijos padiktuotas, išorès priešo supratimas. Netiesiogiai tai patvirtina 1992 m. birželio 8 d. Konstitucinis aktas „Dèl Lietuvos Respublikos nesijungimo į posovietines Rytų sajungas“. Juo siekiama visiems laikams įstatymu atsiriboti nuo Rusijos ir posovietinės erdvès.

Apibrěžiant pagrindines nacionalinės gynybos nuostatas konstitucijoje formuluojami visuomenès ir kariuomenès santykių pagrindai. Konstitucija apibrėždama prezidento, vyriausybes, krašto apsaugos ministro ir kariuomenės vado santykius, įteisina ginkluotuju pajègu pavaldumą demokratiškai išrinktai valdžiai. Valstybės gynimas yra „kiekvieno Lietuvos respublikos piliečio teisè ir pareiga" (139 str.), kurios realizavimo forma yra arba privalomoji pradinè karo tarnyba, arba alternatyvioji krašto apsaugos tarnyba. Už jos nevykdymą yra numatyta administracine ir baudžiamoji atsakomybè. Iš esmés tai gana tipiška modernios valstybès konstitucija, kurioje įtvirtinamos teritorinės gynybos nuostatos.

\subsection{Lietuvos nacionalinio saugumo pagrindụ ịstatymas, 1996}

LR nacionalinio saugumo pagrindu îstatymas yra ilgai užsitęsusių diskusijų saugumo ir gynybos klausimais apibendrinimų rezultatas ${ }^{34}$. Jame formuluojamoje gynybos ir karinių pajègu struktūros ir funkcijų sampratose gana tiesiogiai atsispindi to laikmečio Lietuvos saugumo problemos. Dokumente siekiama pagrịsti Lietuvos kaip tautinès valstybės (modernybės diskursas) ir Lietuvos kaip potencialios NATO ir ES narès (pomodernybès diskursas) saugumo ir gynybos politiką. İstatyme vyrauja modernistinė valstybès, tautos, saugumo ir gynybos samprata. Jame nacionalinio saugumo užtikrinimas yra suprantamas kaip objektyvių grèsmių valstybei ir tautai identifikavimas ir ju neutralizavimas. Dokumente galima įžvelgti tam tikrą normatyvinį disbalansą tarp orientacijos į tautinę valstybę vidaus politikoje ir integracijos į Vakarus (prarandant dali suvereniteto) užsienio ir saugumo politikoje, tačiau vyraujančia tendencija lieka tautinės valstybės saugumas. Tai akivaizdžiai parodo valstybės gynybos samprata. Gynyba yra grindžiama visuotinės ir besąlyginès gynybos principu ${ }^{35}$ :

Gynybos visuotinumas reiškia, kad Lietuvą ginklu gina valstybės ginkluotosios pajėgos, kad gynybai panaudojami valstybės ištekliai, kad kiekvienas pilietis ir Tauta priešinasi visais įmanomais būdais.

Gynybos besąlyginumas reiškia, kad Lietuvos gynyba nėra saistoma jokių sąlygu ir kad niekas negali varžyti Tautos ir kiekvieno piliečio teisès priešintis agresoriui, oku-

\footnotetext{
33 Lietuvos Respublikos Konstitucija 1992, Vilnius: Teisingumo ministerija, 1996.

${ }^{34}$ Žr.: Miniotaitė G., Jakniūnaite D., ,Lietuvos saugumo politika ir identitetas šiuolaikinių saugumo studijų kontekste“, Politologija, 2001, nr. 2, p. 21-43.

${ }^{35}$ Nacionalinio saugumo pagrindų îstatymas, Valstybès žinios, 2, 1997, p. 2-20.
} 
pantui ir bet kam, kas prievarta kėsinasi į Lietuvos valstybės nepriklausomybę, teritorijos vientisumą ir konstitucinę santvarką. Siekdama tarptautinės pagalbos gynybai, Lietuva ginasi ir priešinasi pati, nelaukdama, kada toji pagalba bus suteikta.

Agresijos ar kitu prievartos prieš Lietuvos valstybę atveju piliečiai ir jų susivienijimai priešinasi bet kam, kas prievarta kèsinasi į Lietuvos nepriklausomybę, teritorijos vientisumą ar konstitucinę santvarką. Kiekvienam pasipriešinimo dalyviui taikomas kombatanto statusas pagal tarptautinès teisės aktus". (7 skyrius).

Kaip matyti iš pateiktų citatų, gynybos sampratoje aiškiai juntama Pilènų mito dvasia bei polemika su kapituliacine 1940-ujų metų politika. Joje galima įžvelgti tautos ir valstybės supriešinimą, suteikiant tautai teisę nepaklusti valstybės institucijoms, jei jos atsisako ginti Lietuvos suverenitetą bei konstitucinę tvarką, t. y. gynyba apima ne tik gynybą nuo išorès, bet ir nuo vidaus priešų. Gana logiškai iš tokios gynybos sampratos išplaukia gynybos skirstymas į karinę gynybą, partizaninį karą ir pilietinė gynybą ${ }^{36}$.

Dokumente pateikiama ne tik saugumo ir gynybos samprata, bet ir apibrèžiamos kariuomenès struktūra ir jos funkcijos. Kariuomenè turi būti „ištikima Lietuvos Respublikai, jos Konstitucijai, tarnauti valstybei ir visuomenei, paklūsti Lietuvos piliečių demokratiškai išrinktai valstybės valdžiai“ (18 skyrius). „Kariui ar kariuomenès daliniui negali būti duotas įsakymas, prieštaraujantis įstatymams. Joks kariuomenejje tarnaujantis asmuo negali būti verčiamas tarnauti kitam asmeniui ar asmenų grupei, išskyrus oficialią pareigą. Kariuomenè turi būti rengiama, ugdant kario asmenybę, pilietiškumą ir patriotizmą, profesionalius igūdžius ir kario etiką". Tokią kario ir kariuomenès sampratą atitinka ir ginkluotuju pajẻgų struktūra. Pagal 1996 metų dokumentą jas sudaro reguliariosios pajègos, formuojamos privalomosios karo tarnybos, savanoriu pajėgos ir aktyvusis rezervas. Privalomoji karo tarnyba "yra skirta parengti piliečiams ginkluotai Lietuvos (G.M) gynybai“. Atskiras skyrius dokumente (8 skyrius) išplètojo konstitucijoje suformuluotus „demokratinès kariuomenès ir kitų nacionalinio saugumo institucijų kontrolès“ principus. Tačiau, kaip pažymi K. Paulauskas ir A. Gricius, ,įstatymas nepateikè aiškios parlamentinès priežiūros definicijos ir numatè tik ribotas atskaitomybès bei kontrolès priemones “37.

Vertinant Nacionalinio saugumo pagrindų įstatymą galima teigti, kad dokumente yra universalizuojama ir įteisinama 1992-1995 metu politinès realybės samprata. Tuo metu narystė ES ir NATO atrodè kaip tolima ir sunkiai pasiekiama perspektyva. Nenuostabu, kad dokumente vyrauja teritorinès savigynos nuostatos, ir iš jų išplaukianti kario patrioto samprata. Dokumentą išstūmẻ labiau atitinkantys laikmečio dvasią Nacionalinio saugumo strategija ir LR Karinè strategija.

\footnotetext{
${ }^{36}$ Plačiau žr.: Miniotaitė G., „Pilietinis pasipriešinimas Lietuvos gynybos ir saugumo sistemoje“, Lietuvos metine strateginé apžvalga 2003, p. 195-210.

${ }^{37}$ Gricius (10 nuoroda), p. 225.
} 


\subsection{Lietuvos nacionalinio saugumo strategija $(2002,2005)$}

Lietuvos Nacionalinio saugumo strategija (2002), išlaikydama pagrindines Nacionalinio saugumo įstatymo nuostatas, žymiai plačiau išreiškia Lietuvos transatlantinę orientaciją. Naujame dokumente saugumo objektu išlieka „,valstybės suverenitetas ir teritorinis vientisumas". Tačiau jame taip pat teigiama, kad „šalia nacionalinių saugumo užtikrinimo pastangų Lietuvos Respublika pagal turimus išteklius kartu su tarptautiniais partneriais prisideda prie saugumo ir stabilumo užtikrinimo kituose Europos regionuose, be to, yra pasiryžusi prireikus remtis tarptautinių partnerių pagalba, jei kiltų kriziné situacija Lietuvoje“, t .y. „Lietuvos Respublika tarptautinį saugumą laiko nedalomu ir savo saugumą siekia užtikrinti kaip platesnès regioninès, europinès ir globalinės valstybių bendrijos saugumo neatskiriamą sudedamają dalị “38.

Apibrěžiant grèsmes ir riziką valstybei dokumente susipina bendro ir nacionalinio saugumo nuostatos. Lietuva issipareigoja kovoti su bendromis visoms valstybėms grèsmėmis (terorizmas, korupcija, organizuotas nusikalstamumas, prekyba žmonėmis, narkotikai, nelegali migracija), tačiau didžiausią grèsmę šaliai kelia „energetinė priklausomybė nuo vienos šalies“. Nors ir neįvardinta Rusija išlieka pagrindine grèsme Lietuvos saugumui. Išlieka dokumente ir besąlygiškos teritorinės gynybos, apimančios karinị ir pilietinio pasipriešinimo aspektus, principas. Lyginant 1996 metų saugumo įstatymą ir 2002-ujų saugumo strategiją, pastebimas posūkis prie bendro saugumo sampratos, tačiau gynyba dokumente yra traktuojama kaip atskiros valstybės, o ne bendra (NATO, ES) problema. 2005 metu dokumento redakcijoje, patvirtintoje Lietuvai tapus ES ir NATO nare, mėginama išvengti šio dviprasmiškumo.

Naujoje strategijos redakcijoje (2005) pirmiausiai yra išplečiama jos teisinè bazè. Strategija yra grindžiama ne tik Lietuvos Respublikos Konstitucija, Nacionalinio saugumo pagrindu įstatymu, bet ir Šiaurès Atlanto bei Europos Sajungos sutartimis, NATO ir ES strateginiais dokumentais. Lietuvos saugumo interesai apima ne tik Lietuvos teritorinio vientisumo ir suvereniteto išsaugojimą, bet ir „NATO sąjungininkių ir Europos Sąungos valstybių saugumą, demokratiją ir gerovę; laisvę ir demokratiją kaimyniniuose Europos Sajungos regionuose". Naują turinį dokumente igauna gynybos samprata. Pirmiausiai jame atsisakoma visus ankstesnius dokumentus persmelkiančio visuotinès besąlygiškos gynybos principo ${ }^{39}$. Atsisakius visuotinès gynybos principo, atsisakoma ir civilių gyventoju rengimo pilietiniam pasipriešinimui idejjos. Ją keičia „pilietinio ugdymo“ reikalavimas, kurio paskirtis - skatinti „piliečiu patriotizmą, ryžtą ginti Tèvynę, šalies laisvę“. Strategijoje pabrěžiama, kad ",tautinio tapatumo ir pilietiškumo ugdymo svarbos suvokimas yra nacionalinio saugumo užtikrinimo sąlyga".

\footnotetext{
${ }^{38}$ Lietuvos Nacionalinio saugumo strategija, 2005 http://www.kam.lt/EasyAdmin/sys/files/nacionalinio\%20 saugumo\%20strategija.doc, 2008-09-30.

${ }^{39}$ Visuotinès ir besąlygiškos gynybos principo rudimentu galima laikyti teigini „Gyvybiniams interesams apsaugoti naudojamos visos teisètos priemonès“ (38 nuoroda, 3.1).
} 


\subsection{Lietuvos karinè strategija, 2004}

Nacionalinio saugumo pagrindu ir nacionalinio saugumo strategijos nuostatos gynybos klausimais buvo konkretizuotos LR krašto apsaugos sistemos organizavimo ir karo tarnybos istatyme $e^{40}\left(1998 \mathrm{~m}\right.$.) ir Lietuvos karineje strategijoje $e^{41}$ (2004). 1998 metų įstatyme, apibréžiant kario statusą pažymima, kad karys „yra Lietuvos valstybės gynejjas“ (21 str.), kad karinè tarnyba „reikalauja aukšto lojalumo valstybei lygio“. Tarnyboje turi būti gerbiamas „kario žmogaus orumas", karys „negali būti verčiamas tarnauti kitam asmeniui, ar asmenu grupei“. Be to, karys nèra traktuojamas kaip aklas įsakymų vykdytojas, jis neturi vykdyti įsakymo, jei pastarasis pažeidžia „visuotinai pripažintus tarptautinès teisès principus ir normas" (27 str.). Visumoje įstatymo turinys rodo jo pereinamajji charakterį. Jame susipina nacionalinės ir kolektyvinès gynybos elementai. Krašto apsaugos sistemos struktūra, orientuota į totalinę teritorinę gynybą, bei kario „valstybès gynejjo“ samprata išreiškia nacionalinès gynybos nuostatas. Tuo tarpu kariuomenè rengimas, siekiant ",suderinamumo su NATO struktūromis" rodo, kad įstatymas atsižvelgia ir į kolektyvinės gynybos poreikius.

2004 m. Lietuvos karinëje strategijoje jau visiškai aiškiai įtvirtinamos kolektyvinès gynybos nuostatos: „Lietuvos kariuomenès pajėgos plètojamos pagal tokius prioritetus, kurie stiprina viso Aljanso kolektyvinę gynybą ir pasirengimą, prisideda prie atitinkamų Jungtinių Tautų ir Europos Sajungos greito reagavimo pajègu stiprinimo ${ }^{\prime 42}$. Pereinama nuo grèsmès samprata grindžiamos gynybos politikos prie pajėgumu grindžiamos gynybos koncepcijos. Atitinkamai keičiasi Lietuvos ginkluotuju pajėgų tikslai - ju planavimas orientuojamas i dalyvavimą su penktu straipsniu nesusijusiose operacijose ne tik euroatlantinejje erdvëje, bet ir už jos ribų ${ }^{43}$. Tai iš esmès keičia karinių pajėgumų struktūrą. Prioritetine kryptimi tampa greito reagavimo pajègumų kūrimas.

Šiuos pokyčius ir su jais susijusias problemas gana koncentruotai išreiškè buvęs krašto apsaugos sekretorius R. Norkus: „Ginkluotosios pajègos turi būti pritaikomos sprendžiant terorizmo sukeltas problemas bet kurioje pasaulio vietoje. Lietuvos gynyba prasideda Afganistane, o ne Lietuvos teritorijoje ${ }^{\prime 44}$. Tačiau, jo požiūriu, tokios sąvokos, kaip krizių valdymas, tolimos Afganistano provincijos rekonstrukcija ar taikos palaikymas, sunkiai skinasi kelią į Lietuvos viešąą nuomonę. Gyventojams atrodo nepateisinama laikyti kariuomenę tam, kad ji gesintų miškų gaisrus ar valytų aplinką. Kareivis praranda tautos ir šalies gynejjo įvaizdį. Darosi vis sudètingiau išlaikyti visuomenès paramą bei pateisinti didesnio finansavimo būtinybę. "Sudètingiausia yra pakeisti mąstymą: pradèti galvoti apie Aljanso, o ne tik Lietuvos kolektyvinę gynybą" ${ }^{\prime 4}$.

\footnotetext{
${ }^{40}$ LR krašto apsaugos sistemos organizavimo ir karo tarnybos istatymas, 1998, http://www3.1rs.lt/pls/inter2/ dokpaieska.showdoc_1?p_id=56646,2008-11-5

${ }^{41}$ Lietuvos karinè strategija, 2004, http://www.kam.lt/index.php/lt/34381, 2008-10-28

${ }^{42}$ Ten pat.

${ }^{43}$ Naujausią informaciją apie Lietuvos karių dalyvavimą NATO, ESBO, JT rengiamose tarptautinėse operacijose žr. Lietuvos Krašto apsaugos ministerijos svetainėje: http://www.kam.lt/index.php/lt/104524/.

${ }^{44}$ Žr.: Norkus R., „Defense Transformation: A Lithuanian Perspective“, 11 April 2006, Garmisch-Partenkirchen, Germany. http://www.kam.lt/index.php/lt/96062/, 2008- 09-15.

${ }^{45}$ Ten pat.
} 


\section{Kariuomenès transformacija ir Lietuvos visuomenè}

Panagrinėkime detaliau kaip šis kariuomenès pasikeitimas - nuo tautą ir jos vertybes ginančios nacionalinès šauktiniais grindžiamos struktūros prie profesionaliu greito reagavimo brigadu, atliekančių socialinių ir politinių "gaisrų gesintojų“ vaidmenį visame pasaulyje, - priimamas visuomenès? Ar ją įtikina NATO strateginių dokumentų ir vietinių politikų plačiai taikomas argumentas, kad globaliame pasaulyje vakarietišku vertybių (t. y. žmogaus teisių) gynimas ir sklaida yra moderniausias taikos užtikrinimo būdas? Ar toks pasikeitimas nežlugdo tautinès savimonės, kurios svarbi dalis yra valstybės suvereniteto, siejamo su nacionaline kariuomene samprata? Atsakymai į šiuos klausimus reikalauja gana išsamaus visuomenės transformacijos tyrimo. Čia apsiribosiu tik glausta debatu ir visuomeninės nuomonès tyrimu apžvalga dviem klausimais tiesiogiai susijusiais su kariuomenès pokyčiais: 1) visuomenės požiūris ị būtinają karo tarnybą ir profesionalią kariuomenę ir 2) visuomenės požiūris į Lietuvos karių dalyvavimą tarptautinėse operacijose.

\section{1. Šauktinių ar (ir) profesionalioji kariuomenè?}

1996-2002 m. strateginiuose dokumentuose formuluojamo visuotinès gynybos principo igyvendinimas reikalauja didelio mobilizacinio rezervo. Visuotinè gynyba yra grindžiama šauktiniu kariuomene, karo prievolès įstatymu bei būtinosios karo tarnybos institucija. Pasiruošimas tokio pobūdžio gynybai apima plačius visuomenès sluoksnius, neatsitiktinai visuomenės nuomonės apklausos patvirtina kariuomenès reikšmingumą visuomenejje. Iki karinės reformos prieš įstojant į NATO Lietuvos kariuomenèje tarnavo 22,796 kariai, iš jų 4497 šauktiniai. 2008 metais karių skaičius sumažėjo iki 13,534, iš ju privalomosios tarnybos kariu - 187446. Planuojama, kad jau 2009 metais bus visiškai pereita prie profesionalios kariuomenès. Tačiau, ir visuomenëje, ir politikų tarpe gana plačiai paplitęs požiūris, kad toks perëjimas prieštarautu Lietuvos konstitucijai, kurioje įteisinta privaloma karinė arba alternatyvioji tarnyba.

Pritardama perëjimui prie profesionalios kariuomenès, vyriausybè $2006 \mathrm{~m}$. pabaigoje Seime inicijavo diskusiją. Vyriausybės programoje numatoma palaipsniui mažinti šauktinių kariuomenę. Siūloma, kad ị karinę tarnybą būtų šaukiami tik to pageidaujantys jaunuoliai. Tokiai pozicijai pritaria ir būtinosios tarnybos kariai ${ }^{47}$

\footnotetext{
${ }^{46}$ Factis and Figures: Personnel size in 1998-2009.Žr.: http://www.kam.lt/accessibility/index.php/en/154585/, 2009-02-09.

${ }^{47}$ Žr.: Novagrockienė J., Janušauskienė D., Kaminskaitė A., Mokslinio tyrimo „, Būtinosios tarnybos kariu nuostatos " ataskaita, Vilnius, 2002. Pagal tyrimų duomenis 52, 1 proc. respondentų nuomone, kariuomenè turètų būti sudaryta iš laisvai samdomų žmonių.
} 
ir dauguma gyventoju $u^{48}$. Krašto apsaugos ministerijos analitiku teigimu, tada privalomoji karo tarnyba taikos metu būtų įteisinta ne kaip visuotinè prievolè, bet būtina sąlyga norint tapti aktyviojo rezervo kariu arba kitų jègos struktūru (pavyzdžiui, pasienio apsaugos) pareigūnu. Panašios pozicijos laikosi konservatoriai Ju požiūriu, yra netikslinga visiškai atsisakyti šauktinių kariuomenès. Jei liktų vien tik profesionalai, kariuomenè virtų savo sultyse, prarastų ryšį su visuomene.

Šią mintį Konservatorių partija (nuo 2008 m. gegužès mènesio - Tẻvynès sajungos-Lietuvos krikščionių demokratų partija) išplètojo 2008 metų Seimo rinkimų programoje. Siūloma trišakè Lietuvos kariuomenės struktūra: (1) iš profesionalų sudarytos mobilios pajejgos (8-8,5 tūkst. karių); (2) iš savanoriu sudarytas aktyvus rezervas (apie 12 tūkst. karių); (3) iš savanorių bei šauktiniu sudarytas individualus rezervas (7 savaičių kursai 18-24 metų jaunuoliams). Manoma, kad per vienerius metus būtų galima paruošti apie 7 tūkst. individualaus rezervo, tinkamo mobilizacijai konflikto atveju. Profesionali kariuomenè taip pat traktuojama kaip svarbi krašto saugumo sistemos dalis - numatoma, kad ją sudarys 8000-8500 kariu, dar 12000 - kaip aktyviojo rezervo karių ${ }^{49}$. Atrodo, kad po 2008 metu seimo rinkimų Tẻvynės sajungos-Lietuvos krikščioniu demokratų partijos pozicija taps vyraujančia. Iš esmès, ši tarsi lokali diskusija netiesiogiai kvestionuoja kai kurių NATO ir Lietuvos strateginiu nuostatų suderinamumą. Sutikčiau su Laurynu Kaščiūnu, kad Lietuvai kur kas svarbesnė yra tradicinė Rusijos grèsmė negu globalios grėsmés, nurodomos NATO strateginiuose dokumentuose ${ }^{50}$. Tokio pobūdžio diskusijos rodo, kad Lietuvos politikai į Lietuvos kariuomenė žiūri ne tik funkciniu, bet ir normatyviniu požiūriu. Diskusijos turinys parodo, kad Lietuvos politiniame diskurse prioritetas tebeteikiamas modernybės vertybinèms nuostatoms.

\subsection{Dalyvavimas tarptautinèse operacijose}

Nuo 1996 metų Lietuva vis aktyviau dalyvauja tarptautinėse taikos palaikymo ir taikos atkūrimo operacijose. Per šį laikotarpị daugiau nei du tūkstančiai Lietuvos karių yra dalyvavę dešimtyje tarptautinių operacijų ir dviejose Europos saugumo ir bendradarbiavimo organizacijos misijose. Ypatingai atsakingą vaidmeni Lietuva vaidina Afganistane. Ji nuo 2005 m. vadovauja ISAF Provincijos atkūrimo grupei Vakarų Afganistane, Goro provincijoje. Atkūrimo grupès užduotis - stiprinti centrinès Afganistano valdžios įtaką provincijoje, padėti vietinėms saugumo struktūroms kurti saugią aplinką ir stabilumą, sudaryti tinkamas sąlygas provincijai ir valstybei atsikurti, tarpininkaujant ir

\footnotetext{
${ }^{48}$ Lietuvos gyventojai apie Lietuvos kariuomenę, Baltijos tyrimai, 2006 m birželis, Vilnius 2006. Pagal tyrimų duomenis, 39\% Lietuvos gyventojų nuo 18 metų mano, kad Lietuvai reikètų ir profesionalios, ir šauktinių kariuomenès, o 51\% norètų tik profesionalios kariuomenès. 10\% suaugusių Lietuvos gyventojų nuomonès šiuo klausimu neturi.

${ }^{49}$ Tẻvynès sajungos - Lietuvos krikščionių demokratų programa, Vilnius, 2008.

${ }^{50}$ Žr.: Samoškaitė E. „Koks skirtumas kokia bus kariuomenė?“ Delfi.lt, 2008-08-18
} 
skatinant įvairių valstybinių ir nevyriausybinių organizacijų vystomają veiklą provincijoje. Šiuo metu daugiau nei 200 Lietuvos karių tarnauja tarptautinèse misijose Afganistane, Irake ir Kosove. Kariai misijose įprastai keičiasi kas pusmeti. I tarptautines operacijas vyksta profesinès karo tarnybos kariai, kariai savanoriai, taip pat asmenys, atliekantys civilinę krašto apsaugos tarnybą ${ }^{51}$.

Lietuvos gyventojai karių siuntimą į tarptautines operacijas vertina nevienareikšmiškai. Pagal 2007 metų balandžio mėnesio apklausos, kurią atliko "Spinter tyrimai“ duomenis, 40 proc. gyventoju pritaria tokiai šalies politikai, tačiau pusè apklaustujų neigiamai vertina dalyvavimą misijose. Tuo pačiu 52 procentai Lietuvos gyventoju pripažista, kad Lietuva kaip valstybė turi naudos iš dalyvavimo įvairiose karinèse misijose - tokiu būdu pirmiausia didèja šalies karių profesionalumas, šalis prisideda prie tarptautinio saugumo stiprinimo, tad kartu gerejja ir Lietuvos įvaizdis. Klausiant konkrečiai apie misiją Irake, daugiau kaip pusė apklaustujų (56 proc.) pasisako už Lietuvos karių išvedimą iš šios šalies. Už karių pasitraukimą iš Irako dažniau pasisako moterys, vyresnio amžiaus, žemesnio išsimokslinimo, mažesnių pajamu gyventojai ${ }^{52}$. Savo nuomonę šiuo klausimu taip pat pareiškè internetinio portalo DELFI skaitytojai; iš 12 tūkst. apklausoje dalyvavusių skaitytojų 74 proc. nepritarè karių siuntimui į Iraką ${ }^{53}$.

Kariuomenëje vykstantys pokyčiai nepakeitè visumoje teigiamo gyventoju požiūrio į Lietuvos kariuomenę. Pasitikèjimo kariuomene dinamika 1998-2006 metais rodo, kad pasitikëjimas išaugo nuo 30 procentu 1998 metais iki 54 procentų 2006 metais. Atitinkamai nepasitikējimas sumažejjo nuo 28 procentų iki 12. Pagal „Baltijos tyrimu“" duomenis (2006 m. birželis) daugumos Lietuvos gyventoju nuomone, Lietuvos kariuomenė yra jaunatviška $(80 \%)$, teigiamai reprezentuojanti Lietuva pasaulyje (63\%), geresné nei sovietu armija $(59 \%)^{54}$.

\footnotetext{
${ }^{51}$ Žr. http://www.kam.lt/index.php/lt/144606/, 2008/11/03. Nuo 2004 metų liepos 1 dienos atlikti tarnybą tarptautiniu operacijų kariniame vienete k-ariai yra skiriami, o ne parenkami taikant savanoriškumo principa. Kaip teigia kariuomenès vadas Valdas Tutkus, Lietuvai tapus kolektyvinès gynybos sistemos dalimi, „dalyvavimas tarptautinėse operacijose tapo pareiga“ (Žr.: Stasys Gudavičius, „,Kauno diena“ 2007 vasario mèn. 19 d).

52 Žr.: „Spinter tyrimai“, Delfi.lt, 2007/04/14, http://search.delfi.lt/cache.php?id=F55643E2C4B28568, 2008-10-25.

${ }^{53}$ Žr.: ,,74 proc. DELFI skaitytojų prieš karių siuntimą i̇ Iraką̨, 200702 21, http://www.delfi.lt/news/daily/ lithuania/article.php?id=12216401, 20081020.

${ }^{54} \breve{Z}$ r.: (48 nuoroda).
} 


\section{Išvados}

Ši trumpa Lietuvos kariuomenès sampratos konstravimo oficialiuose dokumentuose analizė bei visuomenės atsako ị juose išreikštas nuostatas apžvalga rodo, kad kariuomenès ir kario samprata neperžengia Lietuvos kultūroje egzistuojančiu - Pilènu (Tèvynès) gynejo ir kario profesionalo, kariaujančio svetimose žemėse, įvaizdžių. Tai rodo istorinių stereotipų bei normatyviniu prielaidų svarbą idealaus kario modelio kūrime. 1990 metais atsikūrusi Lietuvos valstybẻ iš pat pradžiu orientavosi į tarpukario Lietuvos patyrimą. Kuriant kariuomenę bei sprendžiant kariuomenès ir visuomenès santykio problemas, buvo atkurtos tokios institucijos kaip Šaulių sajunga, Ramovè, karinè spauda. Kaip ir tarpukario Lietuvoje, kariuomenė buvo suvokiama ne kaip neutrali demokratijos gyneja, o kaip valstybingumo ir tautiškumo mokykla.

Kario - patrioto, besąlygiško Tévynès gynëjo įvaizdis bei visuotinẻs gynybos koncepcija išreiškia Lietuvos orientaciją i modernistinę tautinę valstybę. Oficialiame politiniame diskurse šis įvaizdis vyrauja maždaug iki 2000-2001metu. Prasidejusios Lietuvos derybos dèl narystės ES sutarties turinio bei aktyvesnis dalyvavimas NATO veiksmu planuose yra pagrindiniai stimulai, keičiantys Lietuvos dokumentų normatyvinị turinį. Naujausiems dokumentams būdingi kai kuriais atvejais prieštaringi mėginimai suderinti uždaros tautinès valstybès ir atviros bendros vertybinès erdvès gynybos nuostatas rodo pereinamaji valstybės pobūdị. Visuomeninės nuomonès kariuomenės transformacijos klausimais apžvalga patvirtina bendrą pagrindinių strateginių dokumentų analizės išvadą - dabartiné Lietuva yra pereinamajame laikotarpyje nuo modernios tautinès valstybès vertybiniu nuostatu prie orientuoto i bendras pilietines vertybes pomodernios visuomenés politinio diskurso.

Bendras pozityvus požiūris ị Lietuvos kariuomenę, i jos modernëjimą ir profesionalëjimą neprieštarauja modernistiniam kariuomenès - valstybės gynëjos įvaizdžiui. Kur kas mažiau entuziastingas Lietuvos kariuomenės dalyvavimo karinėse operacijose už valstybės ribų vertinimas rodo, kad kario žmogaus teisių visame pasaulyje gynëjo įvaizdis dar gana tolimas šiuolaikinëje Lietuvos visuomenejje. Visuotinių žmogaus teisių bei globalistinė grèsmių prevencijos retorika sunkiai skinasi kelią siekiančioje išsaugoti tautinį identitetą visuomenëje. Prasidëjęs perëjimas nuo šauktinių kariuomenės prie profesionalios nėra tik institucinè reforma, mažinanti karių skaičių. Nuo reformos pobūdžio priklauso, ar išliks kariuomenė svarbia tautos identiteto dalimi, ar taps tik dar viena profesija šalia kitu. 